\title{
THE JEWISH HIGH SCHOOL IN BERLIN: DENOMINATIONAL RELIGIOUS EDUCATION BETWEEN THE PUPILS' NEEDS AND THE EXPECTA- TION OF A RELIGIOUS COMMUNITY
}

\author{
Christine Müller \\ University of Hamburg \\ Germany
}

\begin{abstract}
Since the beginning of the early 1990s, Jewish life in Germany has begun to revitalise. Due to the immigration of Jews from the states of the former Soviet Union, the Jewish community in Germany has increased from 30,000 to 120,000 individuals and its age structure has become younger. Jewish communities are hoping for a religious revival among the recent generation of young Jews in Germany. This means that the Jewish schools - and especially religious education faces great challenges. The following article deals as a case study with the Jewish High School in Berlin (JOS). In view of the high expectations of the Jewish community, it appears necessary to gain an insight into the attitude of the pupils towards religion and their desires in religious education.
\end{abstract}

Key Concepts: Jewish pupils, expectations, attitudes, desires, religious education

\section{Question, Topicality and Relevance \\ Question, Goals and Procedure}

The following article deals with a case study in cohesion with the Jewish High School in Berlin. This school was chosen because it is the only Jewish secondary school in contemporary Germany. The re-establishment of this school, the associated hopes of the religious community on the one hand, and the religious self-understanding ${ }^{1}$ and expectation of the pupils in religious education on the other hand, takes centre stage in the study. The argument in this article will be developed in several steps.

First, current developments in the Jewish educational system and the hopes that Jewish parents and religious communities have concerning these institutions will be analysed. In a further section the article deals with the re-establishment and the Jewish profile of this school. This is necessary as to understand the unique composition of the pupils which is heterogeneous from a religious, cultural and social point of view. In a quantitative approach, insight into the religious self-understanding of the young Jews in the school will be provided: How do they understand themselves as Jews in Germany, what is associated with this self-understanding and what religious behaviour arises from it. The emphasis is on the similarities and differences between young Jewish people from German and Soviet ${ }^{2}$ back-

A Jewish conception can be influenced by other factors (e.g. the relationship to the state of Israel, the Holocaust, history and the Jewish people). This article is limited to religion.

The allocation to different groups of origin is based on the socialisation of the pupils, not on the origin of the parents. The parents of the children with German backgrounds also originated from many different countries. 
grounds. This focus is chosen because high expectations on the one hand, and uncertainties and anxieties on the other hand, are associated with immigration. The expectations and desires of the pupils in their religious education are analysed in a qualitative approach. The question concerning the potential achievements of a Jewish religious education for a pupil who is heterogeneous religiously, culturally and socially, and the topics involved with the religious communities, will be asked as part of a survey in the final chapter.

\section{Current Developments in the Educational System of the Jewish Community in Germany}

Since the beginning of the early 1990s Jewish life in Germany has begun to revitalise. Due to the immigration of Jews from the states of the former Soviet Union, the Jewish community in Germany has quadrupled from 30000 to 120000 individuals and the age structure has become younger. This consolidation becomes apparent in the re- and new establishment of Jewish educational institutions ${ }^{3}$ in the last ten years. In 1993 the first Jewish high school subsequent to World War Two began to offer classes (Herz, 1993). The first Jewish primary school in North Rhine-Westphalia was also opened in 1993 in Düsseldorf (Freund, 1996:256). In 2002 the Jewish primary school in Hamburg ${ }^{4}$ opened its doors again, sixty years after being closed by the Nazis. The composition of the pupils of the primary school in Hamburg reflects the changes that are going on within the growing Jewish community. Five out of the eleven pupils in the first class originate from countries of the former Soviet Union (Hartung, 2003:62). The establishment of these schools became possible as a result of immigration by Jews from the Soviet Union. Yet it cannot be explained by the mere fact of immigration alone. The journalist Ginzel pointed out that the generation of Holocaust survivors rejected Jewish schools because they were afraid of a new isolation. Today this fear has turned into another one: The present generation of Jewish parents want a Jewish education for their children because they are concerned that a non-Jewish environment might alienate them further from their religion (Ginzel, 1996:22). A Glance at the state of research shows that it remains uncertain whether these concerns are justified.

\section{State of Research - Directions of (Religious) Development}

The religiousness of young Jewish people in Germany has not been examined thoroughly so far. Only a few contributions deal with the Jewish religious communities in Germany, e.g. Levinson (1986), Kaplan (1994), Brumlik (1995) and Hess and Kranz (2000). There are no empirical studies about the religiousness of Jews in Germany. The only exception is a broad empirical investigation from the 1960s by Oppenheimer (1967), which contains a short consideration of the religiousness of young Jewish people. This lack of research is a serious problem, because changes arise, and no clarity about them has so far been achieved. Jewish voices complain about secularisation, there is an alienation and distance from religion (Wolffsohn, 1991:14) among the long-standing community members. On a long-term

Other criteria (e.g. sex, religious affiliation of both of the parents) might also be relevant, but remain unaccounted for because of the specific subject matter of this article.

3 The large Jewish communities in Germany maintain Jewish kindergartens and primary schools. At the moment, there are primary schools in Munich (since 1967), Frankfurt (since 1966), Berlin (since 1986), Düsseldorf (since 1993), Cologne (since 2002) and in Hamburg (since 2002). There is only one Jewish secondary school in Berlin (since 1993) but there are plans for another secondary school in Frankfurt.

4 For the History and the re-establishment of the Jewish school in Hamburg, (Czudnochowski-Pelz, 1993; Dohnke, 2002). 
basis the immigrants will constitute a new Judaism (Korn, 2003:2), but it remains unclear whether this will also constitute a religious identification. Two positions concerning the future religious development appear particularly noteworthy. There is an optimistic prognosis (1), which is confronted by a rather pessimistic one (2):

- A survey showed that a larger number of younger immigrants hope to find their Jewish identity by a religious orientation (Hess and Kranz, 2000:150). The Jewish community connects this youth with the hope for an albeit modest return to the roots (Neumann, 1999:174; Pinto, 1999). ${ }^{5}$

- In the middle of the $90 \mathrm{~s}$, Bubis doubted whether the immigrants could bring impulses to the content and whether they would remain in the religious communities in the long run (Bubis, 1995:226; Wasserstein, 1999).

Because of these unsecured perspectives, Jewish parents have placed high expectations in the educational work of the schools. It is difficult to develop appropriate concepts as long as nothing is known about the religiousness and the interest of the pupils in religious education. The following empirical study provides an initial idea of the desires and expectations of the pupils. Before the attention can be drawn towards the empirical approaches, is it necessary to provide an overview of the history of the Jewish High School, its re-establishment in 1993, the pupils and the special profile of the school. The history and tradition of the Jewish High School in Berlin point back to the $18^{\text {th }}$ century. It was the first Jewish school in which Jewish and Christian children had the opportunity to study religious and secular subjects together in one classroom. The modern Jewish education began with Moses Mendelssohn (1729-1786). Up to the $18^{\text {th }}$ century, Jewish children were only taught a small amount of writing and arithmetic; the Bible and Talmud were in the centre of their education (Helhlke, 2003:26). The state school was based on Christian principles and excluded Jewish pupils. This situation changes as the Enlightment progressed. Mendelssohn imagined an ideal of a modern Jewish citizen, who combines faith and knowledge without contradictions, combining his religious life with his work in society (Stein, 2003:18). In 1778, David Friedländer, Isaak Daniel Itzig and Moses Mendelssohn founded the Jüdische Freischule in Berlin (Eliav, 2001; Behm, 2002), where the new ideals and the plea for a modern Jewish education were fulfilled. The National Socialists ended this tradition. On 15 April 1942 the school was shut down and for the next three years it was used as a camp for Jews awaiting their deportation to concentration camps. Since 1993 the building has been used in its original role as a Jewish school.

\section{The Jewish High School Berlin}

\section{Motives behind the re-establishment of the Jewish High School}

A Jewish primary school in Berlin was first established in 1986. At the beginning of the 1990s the question about the further school career (Mull, 2003) of these primary pupils arose. After the peaceful revolution in the former East Germany, it became possible to use that building of the Jewish Freischule that lay in the eastern part of Berlin in the Grossen Hamburger Strasse 27 as a Jewish school. In 1993 the school opened its doors as a compre-

\footnotetext{
Two antithetic prognoses are being discussed. The historian Bernard Wasserstein forecasts in his study a Vanishing Diaspora, a coming Europe without Jews. Diana Pinto, consultant for the Council of Europe, sees the requirements fulfilled that Europe could become a new Jewish space. Both authors base their argumentations on the changing situation of the Jewish community in Europe that results from the collapse of the Eastern Bloc. Wasserstein's assertion is based on statistical facts (birth, death, mixed marriage rates) while Pinto articulates her hope for a religious and cultural revival.
} 
hensive secondary school with 18 pupils and a junior high school with nine pupils. The former chairman of the Jewish community in Berlin, Alexander Brenner, saw basically three motives that led to the re-establishment of the school in 1993:

- The continuation of the tradition of the Jewish free school.

- The desire to improve knowledge about Jewish history, religion and Hebrew, to strengthen the connection with Judaism and to sensitise the pupils for issues of antiSemitism and for the conflicts in the Middle East.

- The co-education of Jews and non-Jews and the hope to improve tolerance and mutual understanding as well as abolish prejudices (Brenner, 2003:7).

\section{Composition of the Pupils at the Jewish High School}

From 1993 on, the school had international pupils who were heterogeneous culturally, religiously and socially. Many non-Jewish boys and girls attend this school. When it was re-established in 1993, only one third of the pupils were Jewish. The school has a high proportion of Jewish immigrants. In 1993 already 40\% of the pupils originated from the states of the former Soviet Union. This proportion has increased since then. During the school year 2003/2004 about 300 people from 14 different countries of origin with many different religious backgrounds attended this school (Witting, 2003:15).

\section{Jewish Profile and Religious Education in the Jewish High School}

The Jewish schools in Germany are awarded state recognition and are grant-aided, $90 \%$ of their expenditures are financed by the state. In addition to the national curriculum, these schools offer special classes in Hebrew, Jewish religious education and German language classes for immigrants.

The special Jewish profile of the school is characterised by:

- A kosher school kitchen, graces and kippot for the male pupils,

- The adjustment of the school rhythm to the Jewish holiday calendar,

- The integration of the subjects Bible, religion, Jewish philosophy and Hebrew into the national school curriculum.

Participation in Jewish religious education is compulsory for Jewish and non-Jewish pupils. They have to attend two classes of Bible studies and one class in religion each week from the $7^{\text {th }}$ to $10^{\text {th }}$ grade. In the $10^{\text {th }}$ grade there is an additional class involving introduction to Jewish philosophy. In addition to this pupils of the $10^{\text {th }}$ grade have the opportunity to learn Jewish prayers (Ehrlich, 2003: 80). From the $11^{\text {th }}$ grade onwards the pupils can choose between different standards and classes that last four or five hours a week. In this stage they learn the history of the Jewish people up to the present.

\section{Empirical Approach}

\section{Religiousness of Jewish pupils in the Jewish High School Berlin}

Preliminary Note

The empirical material was obtained in November 2003 (3-7.11.2003). A questionnaire was given to 58 Jewish pupils ${ }^{6}$ in grades 10 to 13 during their religious education classes. The

$6 \quad$ There are 174 Jewish and non-Jewish pupils in these grades. The questionnaire was given to 58 Jewish and 24 non-Jewish pupils. They could choose between two versions of the questionnaire, one contained questions for 
questionnaire consisted of two different parts: First there were questions to tick ${ }^{7}$ that dealt with their religious self-understanding and practice; second there were two questions requiring written answers about the role of religion in everyday life and about their experiences concerning their religious education. Only a few of these aspects were chosen for this article. The pupils were divided on the basis of whether they originated from Germany or the former Soviet Union. ${ }^{8}$ The similarities in the answers of the pupils will first be analysed, afterwards the focus will be directed towards the differences between the different groups of origin. This empirical approach provides the basis for the question concerning the pupils' desires and expectations as to their religious education, which is examined in the next part of the article.

\section{Religious Self-understanding}

Both groups of origin tend towards a conservative or orthodox self- understanding (see table 1). Although the answers provide us with an impression of the religious selfunderstanding of the respondents they should be considered carefully. The quantitative approach contains some difficulties that have to be kept in mind. There is the phenomenon, that strongly religious persons do assess themselves as not very religious because they take religious leaders as their measure while less religious people might assess themselves as very religious even if they only have little affiliation to the religion. These difficulties show the limitations of the quantitative and the necessity of an additional qualitative approach in analysing the religiosity of people. This lack of insight into the meaning behind the answer applies to all quantitative research.

\begin{tabular}{|l|l|l|l|l|}
\hline & Orthodox & Conservative & Reform & Other \\
\hline Total (Jews) & 36,36 & 40,00 & 18,18 & 5,45 \\
\hline $\begin{array}{l}\text { With German } \\
\text { Background }\end{array}$ & 29,63 & 40,74 & 25,93 & 3,70 \\
\hline $\begin{array}{l}\text { With Soviet } \\
\text { Background }\end{array}$ & 42,86 & 39,29 & 10,71 & 7,14 \\
\hline
\end{tabular}

\section{Table 1 (Religious self-understanding)}

\section{Basic Tenets of Faith \\ Belief in God}

The pupils were first asked about their belief in God. Again, a quantitative approach to this question contains some difficulties. People might indicate that they do not believe in God, but they might believe in something that they just do not call God. This shows again the necessity of an additional qualitative approach. In order to obtain a deeper insight into basic tenets of faith in this quantitative approach, additional questions were raised about faith in a certain higher power, in the strength of prayer and in the appearance of a Messiah or a

Christian and/or non-religious pupils, the other contained questions for Jewish pupils. This self-understanding was kept for the analysis. This article is restricted to the Jewish pupils.

7 There were questions about: Religious self-understanding, involvement in community action, attitude towards religious reforms, towards the Torah, attitude towards some aspects of religious practice and basic tenets of faith.

829 of the Jewish respondents were born in Germany or have been in the country for more than ten years. 29 of the Jewish pupils were born in states of the former Soviet Union. 
messianic age. The faith in God (see table 2) is of high importance for the young people. There were hardly any differences between the two groups of origin. Altogether $50.91 \%$ firmly believes in God, an additional $25.45 \%$ believes to a large extent. The answers to the questions about a higher power and the strength of prayer showed similar tendencies. The faith in the appearance of a Messiah, the central element of an orthodox self-understanding, does not play a relevant role for any of the groups of origin.

\begin{tabular}{|l|l|l|l|l|}
\hline & Definitely not & Rather not & $\begin{array}{l}\text { To a large } \\
\text { extent }\end{array}$ & Definitely yes \\
\hline Total (Jews) & 7,27 & 16,36 & 25,45 & 50,91 \\
\hline $\begin{array}{l}\text { With German } \\
\text { Background }\end{array}$ & 3,57 & 17,86 & 28,57 & 50,00 \\
\hline With Soviet Background & 11,11 & 14,81 & 22,22 & 51,85 \\
\hline
\end{tabular}

Table 2 (Belief in God)

\section{Religious Practice}

Frequency of Synagogue Attendance

The young people taking part in the questionnaire were asked about the frequency of their attendance ${ }^{9}$ in the synagogue (see table 3 ). This time the answers given by the two groups showed strong differences. $46.43 \%$ of the young people from a Soviet background attend synagogue only on high holidays. $50 \%$ of the young people from a German background visit the synagogue once a month, a further percentage of $21.43 \%$ at least once a week. A discrepancy between an orthodox self-understanding and personal religious practice is noticeable within both groups of origin.

\begin{tabular}{|l|l|l|l|l|}
\hline & Never & $\begin{array}{l}\text { On High } \\
\text { Holidays }\end{array}$ & Once a month & $\begin{array}{l}\text { At least once } \\
\text { a week }\end{array}$ \\
\hline Total (Jews) & 10,71 & 35,71 & 33,93 & 19,64 \\
\hline With German Background & 3,57 & 25,00 & 50,00 & 21,43 \\
\hline With Soviet Background & 17,86 & 46,43 & 17,86 & 17,86 \\
\hline
\end{tabular}

Table 3 (Frequency of synagogue attendance)

Sabbath

As the perceptions of the day of the Sabbath vary, the respondents were asked whether they make a principle difference between the Sabbath and other days. As seen in the question about synagogue attendance differences appear between the groups. $70.37 \%$ of the young people from the former Soviet Union and $50 \%$ of the young people from a German background never or rarely make a distinction.

It should be considered that the affiliation to a religious community can also have social or economic reasons. The frequency of synagogue attendance provides an insight into the behaviour but not into the motives behind this behaviour. 


\begin{tabular}{|l|l|l|l|l|}
\hline & Never & Seldom & Sporadic & Always \\
\hline Total (Jews) & 27,27 & 32,73 & 23,64 & 16,36 \\
\hline With German Background & 17,86 & 32,14 & 32,14 & 17,86 \\
\hline With Soviet Background & 37,04 & 33,33 & 14,81 & 14,81 \\
\hline
\end{tabular}

Table 4 (Differences between the Sabbath and other days)

\section{Preliminary Summary}

\section{Plurality}

- The quantitative approach has shown that although the respondents assess themselves in a similar manner in regard to faith, this leads to diverse patterns of behaviour.

- It does not matter to what direction of Judaism they officially belong to.

- There is no single way in which the young people understand themselves as Jews, but rather a range and plurality.

\section{Individuality versus Classifications}

- There seems to be neither a religious revival nor a complete turning away from religion during the course of migration among the young Russian immigrants.

- Classifications like the secular Russian are less meaningful ascriptions.

- It is not appropriate to speak of a general secularisation or indifference towards religion. It must be differentiated according to religious practice and faith.

\section{Divergences between Religious Practice and Faith}

- Differences between the groups of origin are to be found in the attitude towards religious practice and not towards religion in general.

- The attitudes towards basic tenets of faith are quite homogenous.

- The respondents separate tenets of faith from religious practice, although it remains unclear what kind of meaning (e.g. to express their affiliation to Judaism, family meetings) the respondents associate with this practices.

\section{Divergences between Theory and Practice}

- The theory (self-understanding, attitude to religious reforms) and practice (synagogue attendance, Sabbath) diverge in both groups of origin. A liberal everyday life practice faces a conservative or orthodox self-understanding.

- The young immigrants might allocate themselves as religious Jews simply because they wish to identify with a group and not because of religious affiliation. They might leave the community once they feel settled in Germany.

\section{Further Work}

- At this point it would be helpful to ask, in qualitative interviews, whether the young people also see a divergence between theory and practice. Maybe this provides evidence of a fundamental changing process in which Orthodoxy loses its (religious) monopoly.

- It should be analysed how the young people constitute their self-understanding and what forms their attitude. 
- The questions raised in the quantitative approach need further investigations in a qualitative approach to consider the meaning behind the answers.

\section{The Pupils' Attitude towards Religious Education}

After certain aspects of the pupils' religiousness have been analysed, the next part of this article will deal with the respondents' perception of their religious education. Although they have given the impression that there are many different aspects, I shall have to concentrate on only a few of them. Basically there is a strong willingness among the pupils to deal with religion as a subject. They have received up to five hours of religious education per week since their $7^{\text {th }}$ grade. Since religious education has a special significance in the school curriculum the attitude of the pupils towards this role is going to be analysed first. Afterwards the expectations, criticisms and suggestions of the pupils will be gathered. This will be done in order to contrast the perspective of the pupils with those of the religious community at the end of this article.

\section{Significance of Religious Education within the School Curriculum}

The pupils do not agree upon the preferable role of religious education within the school curriculum. On the one hand there is a demand to keep it out of the marking system: In my opinion religious education should not be evaluated [17,f., Jewish, Germany/Potsdam]. On the other hand there is a desire to strengthen the position of religious education. This is expressed in the demand for a higher number of hours per week or in the proposal for having religious education as a main subject: I would double the number of hours, since I find that religious instruction is very important [19, f., Jewish, Halle/Saale].

\section{RE is Different than other Subjects}

Religious education not only plays a different role within the school curriculum, it is also different in its structural composition (e.g. because of the possibility of changing the course of events through the pupils' activities). Some of the respondents see religious education as an opportunity to recuperate from the rest of the school day because they feel less pressure in these hours. Others appreciate the opportunity to ask critical questions: In general I really like religious education. First of all because it differs from all other subjects, e.g. during holidays and when we get the opportunity to affect the procedure through critical questions [17, m., Jewish, Berlin]. I see Bible instruction as a very good and informative chill-out hour! [17, f., Jewish, Poltawa/ Ukraine].

\section{Desires and Expectations}

\section{Refusal of Proselytisation}

The respondents have it in common that they reject any kind of proselytisation. They emphasize that a teacher must not try to convince or to urge the pupils to make certain statements. They hope that a teacher will impart knowledge to them so they can become competent enough to decide for or against a religion: I would not only teach about a certain religion, but about the largest religions of the world in religious instruction, without conclusions reached by the teacher concerning which religion is the correct religion. The pupil must decide whether to follow a religion or not and what religion to choose [21, m., Jewish, Ukraine/ Odessa]. 
Assistance with own Religious Orientation

Some pupils hope to get to know their own traditions and customs in religious instruction in order to understand them in a deeper way and to resolve their relationship to God: The religious education gives me the possibility of understanding Judaism better. I did not have the possibility in the Ukraine to take part in such instruction and so I hardly knew anything when I came here. The lessons helped me to understand and determine my relationship to God [21, f., Jewish, Ukraine].

For these young people religious instruction can be a concrete assistance for their life: The topics are very interesting and could make life easier for humans [16, f., Jewish, Berlin].

To Impart Knowledge instead of Faith

For other pupils religious education does not have an impact on their own religiousness. They appreciate the lessons because they provide the opportunity to improve their knowledge about different religions. This knowledge is assumed to be a necessary part of a general educational background: I like religious education but I do not learn to believe or something like that [16, m., Jewish, Berlin]. I like religious education. It is simply good for general education [17, f., Jewish, Riga/Lettland].

Learning about Religious Practice during the Lessons

Religious education in the upper grades of the Jewish High School is philosophically orientated. The pupils value this in different ways and their attitude in this regard corresponds with their expectation concerning religious education in general, as mentioned above. Some of the pupils hope for instruction on religious practice during their religious education classes: More religious education in the form of everyday life (morning prayers). More learning of the Talmud etc. Less philosophy [18, m., Jewish, Ramat Gan/Israel].

\section{Philosophical Approach to Religion}

Other pupils cherish the philosophical approach of the religious education. They were surprised in a positive way because this kind of religious education did not meet their expectations of a denominational religious instruction: I like religious instruction a lot, because there is a high philosophical level, which I have not experienced in a school institution before [18, m., Jewish, St. Petersburg].

\section{Critics and Suggestions for Improvement \\ Lack of Answers for Essential Questions}

Some pupils criticised concrete aspects of the lessons. The teacher obviously cannot give answers to questions like why did God not prevent the Holocaust? This leads to a kind of frustration with religious education among some of the pupils: He [the teacher] cannot answer our questions. He thanks God that he has brought the Nazi period to an end. If he is asked why God has allowed it in the first place, he could not find an answer. I only participate in religious education because I have to [17, m., Jewish, Berlin].

\section{Lack of Variety}

There is the pronounced need for a larger variety of subjects and methods during the lessons. Pupils propose concrete political and social topics (e.g. fascism) to be integrated in 
the curriculum. They criticise that Judaism recurs as a theme in every grade of the school, so they feel that they are constantly repeating themselves during the years: One should not always repeat the same topics in class 1.- 9. They should try to teach as many different topics as possible [16, f., Jewish/Ukraine]. Instruction is interesting, but I would like to treat different topics such as fascism and integration [18, m., Jewish, Afghanistan].

\section{Learning about World Religions}

The pupils hope to acquire basic knowledge about other religions in their lessons. This knowledge is seen as part of a good general educational background that should be offered in the religious education but that is neglected too often: Some things, you have to know, for example who were Jesus and Moses and why did God give the Torah to the people [17, f., Jewish, Riga/Lettland]. Religious education can be interesting, if there is something about other religions in the curriculum but, unfortunately, many teachers do not consider that [16, f, Jewish, Germany].

\section{Final Considerations}

It is difficult to answer the question about the possibilities and limitations of a denominational religious education in the Jewish High School in Berlin. The Jewish High School has pupils who are heterogeneous culturally, religiously and socially. Jews and non-Jews, religious and non-religious young people with German or Soviet backgrounds attend this school. This composition of the pupils which is not to be found in Jewish secondary schools in other countries makes the question about the religious education especially interesting. In other countries such as England, there are different schools for the diverse religious directions of Judaism, in Germany there is only one secondary school for all directions. The school is seen as a flagship for the whole religious community. These expectations imply great challenges for the religious education in that school, because it has to deal with many kinds of different religious affiliations within one classroom.

All in all, there is a willingness amongst the pupils to actively participate in religious education. The teacher should respond to this willingness and consider the needs of the pupils during the course of the lessons. First of all it is important to remember that all pupils reject any form of proselytisation. Most of the respondents do not regard the school as a place to learn religion - this must remain part of the work and responsibility of the religious communities. The respondents showed a strong interest in different religions. This is remarkable, because they are also in a double minority situation with regard to their religion and, for some of them, to their country of origin. This does not lead to separation - it rather leads to frankness towards other religions. Some people see the religious education as an opportunity to learn about their own religion, others wish to improve their level of general knowledge in these lessons. The preferred design of the lessons is equivalent to these expectations. Some respondents hope for a philosophical debate over religion(s), others wish to practice religion during the lessons. In spite of these huge differences in expectations and the rejection of proselytisation, there is a discrepancy between the hopes of the communities for support for a religious revival through religious education, and the needs of the pupils. Therefore the task of the denominational religious education can only be to emphasise the different kinds and levels of knowledge and different forms of religious selfunderstanding. The strong interest in other religions could be used to direct attention to inner-Jewish differences and to contribute in that way towards the integration of oldestablished and new community members. 


\section{BIBLIOGRAPHY}

Behm, BL (Hg) 2002. Jüdische Erziehung und aufklärerische Schulreform. Analysen zum späten 18. und frühen 19. Jahrhundert. (Jüdische Bildungsgeschichte in Deutschland; 5). Münster: Waxmann.

Brenner, A 2003. Grußwort (Vorsitzender der Jüdischen Gemeinde zu Berlin). Jüdische Oberschule zu Berlin (Hg) 2003. Festschrift. 10 Jahre Jüdische Oberschule. 225 Jahre Jüdische Schule in Berlin. Berlin: Selbstverlag. 7.

Brumlik, M 1995. The Development of Jewish Religious Life in Postwar Germany. Speaking Out: Jewish voices from United Germany, ed. Stern, S Berlin: Edition q. 211-218.

Bubis, I 1995. Interview mit Ignatz Bubis (von Michael Brenner). Brenner, M (Hg) 1995. Nach dem Holocaust. Juden in Deutschland 1945-1950. München: CH Beck. 224-227.

Czudnochowski-Pelz, I (Hg) 1993. Talmud Tora - Schule. Mehr als ein Gebäude. Hamburg: Fachhochschule Hamburg.

Dohnke, K 2002. Pausenklingeln und Kinderlachen. Hamburg: Jüdische Schule kehrt an den traditionsreichen Standort im Grindelhof zurück. Jüdische Allgemeine. Wochenzeitung für Politik, Kultur, Religion und jüdisches Leben. (13.03.2002):13.

Ehrlich, A 2003. Bibel/Religion/Philosophie. Jüdische Oberschule zu Berlin (Hg) 2003. Festschrift. 10 Jahre Jüdische Oberschule. 225 Jahre Jüdische Schule in Berlin. Berlin: Selbstverlag. 80-81.

Eliav, M 2001. Jüdische Erziehung in Deutschland im Zeitalter der Aufklärung und der Emanzipation. New York: Waxmann.

Freund, M 1996. Zur Arbeit in den Jüdischen Gemeinden. Ginzel, GB (Hg) 1996. Der Anfang nach dem Ende. Jüdisches Leben in Deutschland 1945 bis heute. Düsseldorf: Droste. 252-259.

Ginzel, GB 1996. Ein Leben zwischen Extremen? Ginzel GB (Hg) 1996. Der Anfang nach dem Ende. Jüdisches Leben in Deutschland 1945 bis heute. Düsseldorf: Droste. 15-36.

Hartung, MJ 2003. Integration hinter Stacheldraht. Die neue jüdische Schule in Hamburg wirbt auf Russisch um Nachwuchs. DIE ZEIT Nr. 29. (10. Juli 2003):62.

Herz, C 1993. Jüdisches Gymnasium in Berlin eröffnet. Kaufmann, U (Hg) 1993. Jüdisches Leben heute in Deutschland. Bonn: Inter Nationes. 103-105.

Hess, R \& Kranz, J 2000. Jüdische Existenz in Deutschland heute: Probleme des Wandels der jüdischen Gemeinden in der Bundesrepublik Deutschland infolge der Zuwanderung russischer Juden nach 1989. Berlin: Logos Verlag.

Kaplan, M 1994. What Is "Religion" among Jews in Contemporary Germany? Reemerging Jewish culture in Germany: Life and Literature since 1989, (eds.) Gilman, SL, Remmler, K. New York: New York University Press. 77-112.

Korn, S 2003. "Es ist normal, dass noch nicht alles normal ist”. Salomon Korn über die Perspektive jüdischen Lebens in Deutschland und die Bedeutung des 27. Januar als Gedenktag. (Im Gespräch mit Matthias Arning). Frankfurter Rundschau Nr. 22. (27.01.03): 2 .

Levinson, PN 1986. Religiöse Richtungen und Entwicklungen in den Gemeinden. Brumlik, M (Hg) 1986. Jüdisches Leben in Deutschland seit 1945. Frankfurt am Main: 
Jüdischer Verlag bei athenäum. 140-181.

Mull, U 2003. Über die Anfänge der Schule. Jüdische Oberschule zu Berlin (Hg) 2003. Festschrift. 10 Jahre Jüdische Oberschule. 225 Jahre Jüdische Schule in Berlin. Berlin: Selbstverlag. 56-58.

Neumann, M 1999. Gemeinschaft oder Gemeinde? Juden in Deutschland heute. Romberg, OR (Hg) 1999. Juden in Deutschland nach 1945. Bürger oder "Mit”-Bürger? Hamburg: Tribüne. 166-175.

Oppenheimer, WJ 1967. Jüdische Jugend in Deutschland. München: Juventa-Verlag.

Pinto, D 1999. Europa - ein neuer “jüdischer Ort”. Menora. Jahrbuch für deutsch-jüdische Geschichte 1999. 15-34.

Stein, D 2003. Traditionelle und moderne Erziehung: Jüdische Erziehungskonzepte von Moses Mendelssohn, Samson Raphael Hirsch und Franz Rosenzweig. Jüdische Oberschule zu Berlin (Hg) 2003. Festschrift. 10 Jahre Jüdische Oberschule. 225 Jahre Jüdische Schule in Berlin. Berlin: Selbstverlag. 18-25.

Wasserstein, B 1999. Europa ohne Juden. Das europäische Judentum seit 1945. Aus dem Englischen von Bernd Rullkütter (Engl.: Vanishing Diaspora. The Jews in Europe since 1945. Cambridge 1996). Köln: Ullstein Taschenbuchverlag.

Witting, B 2003. Vorwort. Jüdische Oberschule zu Berlin (Hg) 2003. Festschrift. 10 Jahre Jüdische Oberschule. 225 Jahre Jüdische Schule in Berlin. Berlin: Selbstverlag. 14-15.

Wolffsohn, M 1991. Auf dem Weg in die Normalität? Zur Situation der Juden in Deutschland heute. Bundeszentrale für politische Bildung (Hg) 1991. Deutsche JudenJuden in Deutschland. Bonn: Verlag der Bundeszentrale für politische Bildung. 12-15. 